\title{
Impacts of Earnings Quality and Debt Maturity on Investment Efficiency: Study Case in Vietnam
}

\author{
Dang Ngoc Hung ${ }^{1}$, Vu Thi Thuy Van ${ }^{2} \&$ Nguyen Thi Thanh Phuong ${ }^{3}$ \\ ${ }^{1}$ Hanoi University of Industry, Vietnam \\ ${ }^{2}$ National Economics University, Vietnam \\ ${ }^{3}$ Thuongmai University, Vietnam \\ Correspondence: Dang Ngoc Hung, Hanoi University of Industry, Vietnam.
}

Received: December 15, 2019

Accepted: March 16, 2020

Online Published: July 7, 2020

doi:10.5430/ijfr.v11n4p421

URL: https://doi.org/10.5430/ijfr.v11n4p421

\begin{abstract}
The paper analyzed the impact of earnings quality (EQ), debt maturity, investment efficiency (IE) of listed companies on Vietnam stock market thanks to the regression methods of FEM, REM and GLS and data of enterprises in the period of 2010 - 2018. The research findings have shown that EQ and debt maturity have a positive impact on EI, in which EQ has a stronger influence than debt maturity. A review of both EQ and the debt maturity for overinvestment or underinvestment indicated a positive impact and the stronger impact on overinvestment. Based on the research findings, the authors have put forth several recommendations for investors, businesses and policy makers.
\end{abstract}

Keywords: earnings quality, debt maturity, investment efficiency

\section{Introduction}

Earnings quality (EQ) of businesses is an important factor to minimize the information asymmetry and thus promote the development of financial markets. EQ can be viewed as the potential earnings growth of the business or the possibility that the business will achieve the expected earnings growth in the future. The company's stock value, therefore, depends not only on its earnings per share but also on its future performance expectations and its reliability of earnings expectation.

The reporting corporate earnings may not be authentic compared to the real one. The cause is due to the distortion of the declared earnings of the business arising from the conflict of interest between the manager and business owner as well as accounting constraints in the business such as errors in forecasting and estimating future values or using inadequate accounting methods that have made the differences between expected earnings and those stated in financial statements. EQ is an honest representation of the predicted earnings and the declared ones, and the published earnings will be of great use to users in making relevant decisions. According to the authors (Richardson, Sloan, Soliman, \& Tuna, 2001) EQ was evaluated based on the stability of future revenue and (Beneish \& Vargus, 2002) also deemed that the stability of corporate revenue will prove the corporate EQ. (Penman \& Zhang, 2002) defined EQ as the possibility to forecast future income of an enterprise. Investors or relevant parties on the capital market often rely on information stated in the financial statements to assess the future cash flow of the firm from which the expected earnings can be estimated (J. Francis, LaFond, Olsson, \& Schipper, 2004). Therefore, in order to better predict the future cash flow, the profit announced in the financial statement should be of good quality.

Investment is one of the key and thorough activities of every firm. For growing and development, businesses are required to conduct investment activities to increase profits for themselves. However, the investment of an enterprise is not always beneficial if the planning and management of the enterprise's investment activities are not strictly and scientifically carried out. Especially in the evaluation step to select investment implementation, if the enterprise does not focus on full analysis of the factors related to the investment project such as planning, finance, human resources, economics and society, the environment ..., it can lead to the decision to implement inefficient projects or omit good projects for the company. In addition to the above factors, businesses often overlook the importance of in-depth analysis of a tool that is both convenient and highly useful and available, that is, their financial statements. A number of recent theories and studies have shown that EQ contributes to improving the efficiency of business investment as well as playing an important role in limiting overinvestment and promoting investment for enterprises of underinvestment. 
In addition, these studies also discovered the relationship between debt maturity with IE as well as explained this in the direction that short-term debt contributed to reducing representative problems and information asymmetry.

During the past time, there have been many studies on the relationship between EQ and debt maturity affecting IE, such as those conducted by (Gomariz \& Ballesta, 2014), (Cherkasova \& Rasadi, 2017), (De Carvalho, Kalatzis, \& De Albuquerque, 2014), (Li, 2011), (Houcine, 2017), (Kim \& Verrecchia, 1994), (Bushman \& Smith, 2001), (Healy \& Palepu, 2001), (Hope \& Thomas, 2008), (Biddle \& Hilary, 2006), (McNichols \& Stubben, 2008), (Biddle, Hilary, \& Verdi, 2009), (Chen, Hope, Li, \& Wang, 2011), (Hung, Ha, \& Binh, 2018), (H. N. Dang, Vu, Ngo, \& Hoang, 2019), (Van Linh, Hung, Dang, Van, \& Anh, 2019), (N. H. Dang, Tran, \& Tran, 2019), (Nguyen \& Nguyen, 2019). The findings of these studies are not homogeneous whether EQ is positively or negatively related to IE? and how does it affect the case of overinvestment or underinvestment businesses? For Vietnam, a developing economy, as the problem of information asymmetry still has big gaps, do EQ, the debt maturity have an impact on IE? Therefore, this study is aimed at examining the empirical results on the impact of EQ, debt maturity on IE.

\section{Research Overview}

\subsection{Impacts of Earnings Quality (EQ) on Investment Efficiency (IE)}

Investment efficiency (IE) includes all the benefits brought about by the implementation of the investment, as a result of a comparison between the outputs and the input costs of the investment process. Investment decisions have an impact on the use of capital as well as the benefits and returns; therefore, before deciding to invest, investors need to carefully master the information through a variety of tools and measures. One of the most convenient, available and useful information channels for organizations and individuals to analyze and appraise an enterprise's investment is its financial statement. A proper financial statement will help businesses and investors best assess the firm, thereby selecting projects with appropriate scale and level of investment, bringing in high efficiency. The following papers offered several explanations of the impact of EQ on IE.

In recent years, there have been several related studies such as (Cherkasova \& Rasadi, 2017) studying the relationship between EQ and IE. The study was conducted on a sample of 7546 companies from Eastern Europe in the period of 2010-2015. Research findings have shown that a higher EQ minimizes both overinvestment and underinvestment. The relationship between EQ and under-investment is stronger in the industrial sector. Meanwhile (De Carvalho et al., 2014) conducted this study to verify whether the EQ of Latin American companies had an influence on IE decisions, overinvestment and underinvestment or not? The authors used logit model and data from those companies of seven Latin American countries. The results indicated that poor EQ reduced the possibilities of effective investment decisions and increased the likelihood of underinvestment.

(Li, 2011) considered a new approach to measure EQ. The author measured EQ as a concurrent relationship between changes in capital levels and labor investment as well as the change in reported earnings. The author discovered that EQ measures based on managerial labor and capital decisions are positively correlated with the sustainability of earnings. (Houcine, 2017) reviewed the impact of financial statements quality on corporate IE. Our sample was based on 25 companies listed in Tunisia in the period of 1997-2013. The study found the confirmation that certain characteristics of financial information, in particular reliability and stability, were positively related to IE, while EQ was in principle of prudence and the appropriateness of earnings information had no significant influence on the investment decision.

The research conducted by (Kim \& Verrecchia, 1994) suggested that voluntary disclosure of information stated in corporate financial statements contributed to reducing information asymmetry, enabling investors capture and better understand the financial situation of the business. Therefore, for businesses with a high level of information transparency, investors can be relatively confident that any securities transaction taking place at a "fair price" increases the stock liquidity of the business. According to the above authors, the financial statement is a bridge to help investors evaluate and consider the cash flow of the business, and at the same time, the information stated in the financial statement has wide application because the revenue disclosure in such reports plays a key role in determining the stock price as well as capturing the management of the company and the implementation of investment projects. In addition, studies suggested that the disclosure of the liquidity of a stock in the financial statement would be associated with an increase in investment in that stock. Furthermore, according to the theory of representative costs, there are various controls to minimize information asymmetry and information risk in order to better monitor management activities, thereby reducing managerial opportunity behaviors such as EQ tools and disclosure of information. This has been theorized and analyzed in details in the paper of (Bushman \& Smith, 2001), (Healy \& Palepu, 2001), (Hope \& Thomas, 2008). 
Together with those studies, a number of other researches have debated and found out the evidence that EQ reduced the sensitivity of cash flows of investment (Biddle \& Hilary, 2006), as well as restricted overinvestment due to the managed information distortion (McNichols \& Stubben, 2008). Accordingly, the study by (Biddle \& Hilary, 2006) deemed that the quality of the financial statement helped strengthen IE by reducing the information asymmetry between managers and investors. To make this clear, (McNichols \& Stubben, 2008) suggested that a low EQ can mask the underlying trends in revenue and profit growth. Therefore, an overestimation of earnings due to failure to grasp the errors in the financial statements may lead to overinvestment. (Biddle et al., 2009), (Chen et al., 2011) tested the effectiveness of EQ on two inefficient scenarios, overinvestment and underinvestment. The result of authors once again confirmed that a higher EQ helped underinvestment companies increase their investment and overinvestment ones restrict their own investment.

What's more, previous studies have revealed that EQ is higher in public companies than in private companies (Ball \& Shivakumar, 2005), (Burgstahler, Hail, \& Leuz, 2006) as well as in other countries where law protection and enforcement are higher (Leuz, Nanda, \& Wysocki, 2003), (Holthausen, 2009). Accordingly, in their paper on English law of (Ball \& Shivakumar, 2005), the authors argued that the financial statements of private enterprises must be audited and complied with accounting standards as well as corporate tax laws. With the assumption that the financial statements of private enterprises are of lower quality than those of public enterprises, the authors concluded that private enterprises can use the financial statements to reduce the information asymmetry between managers and the other relevant parties. In addition, EQ also had an impact on a part of corporate income as stated in the research by (Bhattacharya, Daouk, \& Welker, 2003). The results showed that the unclear increase in national income was related to the decline in that country's stock market trading. An enterprise's unclear income is a complex interaction among three factors: management dynamics, accounting standards and the implementation of accounting standards (auditing quality). To clarify the above problem (Leuz et al., 2003) found an endogenous link between corporate governance and EQ. The regression results showed that management of earnings was negatively correlated with the rights of minority shareholders and the exercise of power. Internal incentives for income management was a way to conceal their control interests and he argued that accounting principles could limit the management possibility of incomes of insiders. On the other hand, the paper of the authors (Lambert, Leuz, \& Verrecchia, 2007) examined the data and explored the impact of accounting information on corporate capital costs. He proved that the quality of accounting information can affect capital costs both directly and indirectly. On the direct side, high quality information disclosure will help reduce the variance of cash flow fluctuations of businesses. Indirectly, the disclosure of high quality information has an influence on the corporate decision, thereby changing its ratio of corporate future cash flows on the covariance of cash flows and the sum of cash flows in the market.

\subsection{Impacts of Debt Maturity on Investment Efficiency}

Beside the impact of EQ, the paper also explored the impact of debt maturity on corporate IE. Accordingly, with the use of various short-term debts, it is possible to minimize the problem of information asymmetry and representation between managers, shareholders and creditors. The use of short-term debt will contribute to the ability to control managers, helping lenders have closer contact with borrowers, thereby making it easier to determine business results of the firm at an early stage, so that they can then decide whether to extend or change the terms of the contract with the borrower. In addition, studies suggested that using short-term debts will improve overinvestment and underinvestment. According to the research by (Myers, 1977) debt maturity could be used to minimize overinvestment and underinvestment issues. When there were projects of positive NPV, businesses can finance such projects with short-term debts to ease the problem of underinvestment. Firms utilized short-term debts because they would be liquidated in a short time and the profits will belong entirely to the business. (Barclay \& Smith Jr, 1995) suggested that determinants of corporate debt maturities supported the hypothesis that firms would have more growth opportunities and investment opportunities when producing more short-term debts. Moreover, enterprises with information asymmetry have the potential to issue more short-term debts. A firm with predominant public debts will omit the implementation of a growth opportunity. On the bank's side, with a short-term debt, they may impose additional repayment conditions. This indicated that high-growth businesses would opt for bank loans rather than public borrowings and private non-bank loans.

When considering small businesses, the study (Berger \& Udell, 1998) suggested that small businesses often had unaudited financial statements with not many assets that could be easily assessed for pledge or mortgage; there were few credit or income records for external providers to review. As a result, these enterprises could normally borrow short-term loans instead of long-term loans. One reason for the fact that small businesses often have less access to long-term debt is the intransperancy and more risks of information than that in larger firms. Next, when studying the impact of short-term debts on costs of capital, the study by (Childs, Mauer, \& Ott, 2005) deemed that flexible debt 
policy encouraged enterprises to opt for short-term debts, leading to the decrease in agency costs and at the same time, discouraged businesses from choosing high initial debt levels. However, the decrease in agency costs can slow down the corporate enhancement of leverage because the selection of the initial debt level of the business depends on the choice of the growth level in planning investment opportunities. However, most businesses opt for long-term loans because of the effects of cost issues related to short-term debts such as issuance costs or liquidity risks. Short-term debt may mitigate or completely resolve conflicts, but businesses only opt for short-term debt when it has high financial flexibility to adjust future debt levels. Enterprises themselves can overcome this problem by reducing their debt levels upon poor business conditions.

The study conducted by (Ortiz-Molina \& Penas, 2008) learned about what determined the maturity of these corporate loans. They discovered that the debt maturity is associated with pledges, the financial status of the company, good credit history and less shortage of information from borrowers. The evidence in the article suggested that using debt with a shorter term to negotiate the terms of the contract took place quite often, thus enabling the close monitoring of borrowers. As a result, shorter debt maturity supportted in minimizing the consequences of information asymmetry between borrowers and lenders. Research findings showed that businesses often preferred collateral to borrow long-term loans, as this translated risks to collateral and reduced the probability of insolvency of businesses due to pressure to repay debt being extended over a longer term. Secondly, business owners with poor personal credit were often given loans with shorter terms, because creditors were afraid of risks and had to supervise customers of higher risk more closely. These two results provided strong evidence for the role of debt maturity in solving information asymmetry.

\subsection{The Relationship Between EQ and Short-Term Debt Maturity on Investment Efficiency}

The research papers presented in section 2.1. and 2.2 both showed a separate relationship between EQ and short-term debt to the corporate IE. Combining these above results, the authors (Gomariz \& Ballesta, 2014) tested these relationships on a sample of 13,500 businesses in Spain in the period of 1997-2008. The study used PooledOLS model and then used two-stage regression model and GMM model to closely examine the above relationships. The results revealed that the better quality of financial statements and the use of short-term debts (low-term debt) increased the investment efficiency. However, if there existed a distinction between overinvestment and underinvestment, EQ would then only play a role in reducing overinvestment. In contrast, the use of short-term debt is a mechanism that contributes to EI enhancement in both overinvestment and underinvestment scenarios. In addition, this study found evidence that EI and low-term debt had an alternative relationship in improving IE: For businesses with lower levels of short-term debt use, the impact of EQ on IE is higher than that of enterprises with higher levels of short-term debt use. This showed that in enterprises with EQ, using debts is the main mechanism used by creditors to control managerial behavior and limit loss of benefits. On the other hand, in companies with more EQ, financial statements are used to monitor investment inefficiencies.

\section{Research Model and Approaches}

\subsection{Research Model}

This study used regression models proposed by (Gomariz \& Ballesta, 2014) to clarify the relationship between EQ and debt maturity with companies' IE as discussed in the literature review. Specifically:

The model tested the impact of $E Q$ and debt maturity on the corporate investment efficiency:

$$
\operatorname{INVEFF}_{i, t}=\beta_{0}+\beta_{1} \mathrm{EQ}_{i, \mathrm{t}}+\beta_{2} \mathrm{SDEBT}_{\mathrm{i}, \mathrm{t}}+\beta_{4} \mathrm{SIZE}_{\mathrm{i}, \mathrm{t}}+\beta_{5} \operatorname{Tang}_{\mathrm{i}, \mathrm{t}}+\beta_{6} \mathrm{SdCFO}_{\mathrm{i}, \mathrm{t}}+\beta_{7} \mathrm{SdREV}_{\mathrm{i}, \mathrm{t}}+\varepsilon_{\mathrm{i}, \mathrm{t}}
$$

$\operatorname{INVEFF}_{i, t}=\beta_{0}+\beta_{1} \mathrm{EQ}_{\mathrm{i}, \mathrm{t}}+\beta_{2} \mathrm{SDEBT}_{\mathrm{i}, \mathrm{t}}+\beta_{3} \mathrm{EQ}^{*}$ DumSDebt $_{\mathrm{i}, \mathrm{t}}+\beta_{4} \mathrm{SIZE}_{\mathrm{i}, \mathrm{t}}+\beta_{5} \operatorname{Tang}_{\mathrm{i}, \mathrm{t}}+\beta_{6} \mathrm{SdCFO}_{\mathrm{i}, \mathrm{t}}+\beta_{7} \mathrm{SdREV}_{\mathrm{i}, \mathrm{t}}+\varepsilon_{\mathrm{i}, \mathrm{t}}(2)$ In which: INVEFF $F_{i, t}$ is the dependent variable representing IE of the firm $i$ in year $t$

As specified in the literature review, IE was defined and measured in various ways. This study is based on the recommendations from the study by (Biddle et al., 2009). According to these authors, IE was measured based on the remainders in the regression between investment and growth opportunities (calculated by revenue growth), because the above authors considered the errors in the relationship between investment and revenue growth represented inefficiencies in investment. Thus, the investment efficiency variable in this paper is determined as follows:

$$
\text { Investment }_{\mathrm{i}, \mathrm{t}}=\beta_{0}+\beta_{1} \text { SalesGrowth }_{\mathrm{i}, \mathrm{t}-1}+\varepsilon_{\mathrm{i}, \mathrm{t}}
$$

In which:

Investment $\mathrm{i}, \mathrm{i}$ is total investment of enterprise $\mathrm{i}$ in year $\mathrm{t}$ and is measured by the difference of fixed assets between two consecutive years over the total assets of the previous year, specifically as follows: 


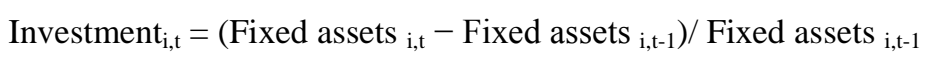

SalesGrowth $_{\mathrm{i}, \mathrm{t}-1}$ : is the change in turnover of enterprise $\mathrm{i}$ from year $\mathrm{t}-2$ to year $\mathrm{t}-1$, determined as follows:

$$
\text { SalesGrowth }_{\mathrm{i}, \mathrm{t}-1}=\left(\text { Turnover }_{, \mathrm{t}-1}-\text { Turnover }_{\mathrm{i}, \mathrm{t}-2}\right) / \text { Turnover }_{\mathrm{i}, \mathrm{t}-2}
$$

$\varepsilon_{i, t}$ is the remainder of the regression model. This remainder reflects the error compared to the expected investment and therefore, is used as the basis for IE measurement (INVEFF variable). This dependent variable is defined as the absolute value of the remainder from equation (3) multilplied by (-1).

INVEFFi,t $=-\left|\varepsilon_{\mathrm{i}, \mathrm{t}}\right|$

To measure EQ, in this study we measured through the variability of profits. EQ is represented through the variability of profits. The larger the standard deviation of profit, the more volatile corporate profits are implied. Enterprises with strong variability in profits are signs of poor profit quality (J. Francis et al., 2004), (J. R. Francis \& Wang, 2008), (Dichev \& Tang, 2009), (Rezaee \& Tuo, 2017).

$$
\text { VARIA }_{\mathrm{i}, \mathrm{t}}=\sigma(E A R N i, t)
$$

DumSTDebt $_{\mathrm{i}, \mathrm{t}}$ : is a dummy variable representing the level of short-term debt use. Based on the recommendations of the authors (Gomariz \& Ballesta, 2014), the study compared the standard deviation of short-term debt of each enterprise by year and the median of the deviation of short-term debt of the entire samples.

The remaining variables in the research model are measured and presented in Table 1.

Table 1. Control variables in the research model

\begin{tabular}{lll}
\hline Variable & Variable code & Measurement \\
\hline Debt maturity & SDEBT & Short-term debt/Total outstanding debt \\
\hline Firm size & SIZE & Firm size by Log property (Total assets) \\
\hline Tangible fixed assets & Tang & Tangible fixed assets/Total assets \\
\hline $\begin{array}{l}\text { Fluctuation of corporate cash } \\
\text { flow }\end{array}$ & sdCFO & $\begin{array}{l}\text { Standard deviation (Cash flow from business activities/Total } \\
\text { assets at the beginning period) }\end{array}$ \\
\hline Volatility of corporate revenue & sdREV & $\begin{array}{l}\text { Standard deviation (Revenue/ Total assets at the beginning } \\
\text { period) }\end{array}$ \\
\hline
\end{tabular}

Source: Established by the author

\subsection{Research Hypotheses}

Based on the viewpoints on the relationship of EQ and debt maturity for corporate IE, as well as based on the findings of previous empirical studies, we would like to put forth the following research hypotheses:

Hypothesis H1: EQ has a positive impact on corporate IE.

Hypothesis H2: Debt maturity has a positive impact on corporate IE.

Hypothesis H3: EQ is positively related to the corporate overinvestment and underinvestment.

Hypothesis H4: Debt maturity is positively related to the corporate overinvestment and underinvestment.

H5: The impact of EQ on IE of the firm with high short-term debt ratio will be higher.

\subsection{Research Data}

The paper examined the relationship between EQ and debt maturity for IE of listed companies on Vietnam Stock market in the period of 2010-2018 with 4704 observations. The data of these companies have been collected from the financial statements of businesses and Vietstock data sets, as well as aggregated from the data published on some reputable securities websites such as cafef.vn or cophieu68.com. The research paper compiled data of companies from 2008 to 2018; however, based on recommendations from authors (Gomariz \& Ballesta, 2014) on how to measure IE variables as well as the regression of capital flows based on cash flows in years $\mathrm{t}-2$, $\mathrm{t}-1$; therefore, from 11 years collected as above, the sample of the study applied to the regression models as mentioned have been reduced to only 9 years from 2010 to 2018. The original data were aggregated and recalculated according to the method of determining 
the variable, in which some variables were regressed to get the remainder and initialize new variable respectively via Stata 14.0 software. Thus, the final sample of the study had 4704 enterprise observations in the period of 2010-2018.

\subsection{Research Method}

The study used the Fixed Effect and Random Effect regression methods to estimate the relationship between EQ and debt maturity for IE of listed companies in Vietnam in the period of 2010-2018. The research paper used F-Test and Hausman tests to look into which would bring in better results, the Fixed Effect or Random Effect methods, thereby checking the defects of the selected model and finding the solution to the model by using the GLS method.

\section{Research Findings and Discussion}

Table 2 presented the statistical results describing the variables included in the regression model. The average investment efficiency of Vietnamese enterprises in the period of 2010-2018 was -0.492. Meanwhile, overinvestment had an average value of $-1,124$ and underinvestment of average value of $-0,315$. These values are compatible with those in the studies of (Chen et al., 2011), (Gomariz \& Ballesta, 2014). Going further, Table 1 showed that about $21.89 \%$ of enterprises are in the over-investment group, so it can be concluded that the majority of enterprises fall under the level of underinvestment. This result is consistent with that of the paper (Chen et al., 2011) when studying the enterprises in the emerging market. This result also confirmed that the majority of Vietnamese enterprises and the emerging market encountered limitations in raising funds for projects, thereby reducing the investment efficiency. Table 2 also provided an overview of the EQ measurement variables, whereby these variables had an average of -0.029. The debt maturity had an average value of 0.820 , including businesses that do not use short-term debts and some businesses choose to use all short-term debt in their debt structure. In general, Vietnamese enterprises have a high ratio of short-term debt to total debt, accounting for nearly $82 \%$, showing that the demands for loans to supplement working capital and investment in small projects as well as short-term projects of Vietnamese businesses are relatively large. On the other hand, we can see that the ratio of fixed assets to total assets of Vietnamese enterprises has an average value of $20.2 \%$ with the highest value of $96.6 \%$. The standard deviation of cash flow from operating activities on averages was $9.5 \%$ and revenue of $21.1 \%$.

Table 2. Descriptive statistics

\begin{tabular}{llllll}
\hline Variable & Obs & Mean & Std.Dev & Min & Max \\
\hline INVEFF & 4704 & -0.492 & 0.963 & -13.091 & 0.000 \\
\hline OVER & 1030 & -1.124 & 1.908 & -13.091 & 0.000 \\
\hline UNDER & 3674 & -0.315 & 0.159 & -1.103 & -0.001 \\
\hline EQ & 4704 & -0.029 & 0.035 & -0.246 & 0.000 \\
\hline SDEBT & 4704 & 0.820 & 0.224 & 0.014 & 1.000 \\
\hline SIZE & 4704 & 27.107 & 1.510 & 23.330 & 33.294 \\
\hline Tang & 4704 & 0.202 & 0.197 & 0.000 & 0.962 \\
\hline sdCFO & 4704 & 0.095 & 0.117 & 0.000 & 1.508 \\
\hline sdREV & 4704 & 0.211 & 0.315 & 0.000 & 8.099
\end{tabular}

Source: calculated by the author from Stata 14.0

Table 3. Correlation matrix

\begin{tabular}{llllllll}
\hline & INVEFF & EQ & SDEBT & SIZE & Tang & SdCFO & sdREV \\
\hline INVEFF & 1 & & & & & & \\
\hline EQ & 0.0838 & 1 & & & & & \\
\hline SDEBT & 0.0671 & -0.048 & 1 & & & & \\
\hline SIZE & -0.0088 & 0.0543 & -0.3544 & 1 & & & \\
\hline Tang & -0.0069 & 0.0135 & -0.3639 & 0.0262 & 1 & & \\
\hline SdCFO & -0.0548 & -0.1366 & 0.0996 & -0.0963 & -0.1456 & 1 & \\
\hline SdREV & -0.0366 & -0.246 & 0.1617 & -0.1016 & -0.1157 & 0.3056 & 1 \\
\hline
\end{tabular}

Source: calculated by the author from Stata 14.0 
Table 3 presented the autocorrelation matrix, showing the direction of impact among the study variables. First, it can be seen that the EQ variable is positively related to the corporate IE. Similarly, short-term debt maturity variable is positively correlated with IE. In contrast, the control variables in the model are negatively correlated with IE. At the same time, the purpose of checking the close correlation between independent variables and dependent variables is to eliminate factors that may lead to multicollinearity before running regression models. The correlation coefficient among the independent variables in the model does not have any pair greater than 0.8 , so multi-collinear phenomena is less likely to occur, when using the regression model, the authors group adopted VIF for testing.

The study conducted regression of dependent EQ variable and debt maturity variable along with control variables according to Fixed Effect and Random Effect. After that, the paper used F test, Breusch-Pagan Lagrange Multiplier test and Hausman test to select the appropriate model. These tests have all given the same result in which using the Fixed Effect method would bring in better regression results. Then, the study continued to use the heteroscedasticity test to ensure the soundness of the model; however, the results indicated that the heteroscedasticity occurred. Therefore, the research paper conducted regression by GLS method.

To measure the impact of EQ and short-term debt on IE of enterprises, the study used the model (1). The regression results of this model are presented in Table 4, all three methods, Fixed Effect, Random Effect and GLS all showed the positive relationship between EQ and the IE variable of the firm and of $1 \%$ statistical significance. Similarly, the regression coefficients of the debt maturity with the dependent variable are positive and of $1 \%$ statistical significance. Accordingly, an increase of one unit in the ratio of short-term debt to total debt will bring an additional of 0.376 units to IE of the firm. It is noted that the impact of the EQ is much higher than that of debt maturity for IE. Thus, hypotheses $\mathrm{H}_{1}$, $\mathrm{H}_{2}, \mathrm{H}_{3}, \mathrm{H}_{4}$ are accepted. With respect to the control variables, only the cash flow fluctuations of enterprises is negatively related to IE; the remaining factors are not statistically significant.

Table 4. Regression results of investment efficiency

\begin{tabular}{|c|c|c|c|c|}
\hline & VIF & FEM model & REM model & GLS model \\
\hline EQ & 1.08 & $1.967 * * *$ & $1.888^{* * *}$ & $2.101 * * *$ \\
\hline SDEBT & 1.36 & $0.380 * * *$ & $0.514 * * *$ & $0.376 * * *$ \\
\hline SIZE & 1.17 & 0.00629 & -0.0451 & 0.00745 \\
\hline Tang & 1.19 & -0.14 & $-1.624 * * *$ & 0.0747 \\
\hline sdCFO & 1.13 & $-0.360 * * *$ & $-0.398 * * *$ & $-0.370 * * *$ \\
\hline sdREV & 1.18 & -0.0409 & 0.00281 & -0.046 \\
\hline _cons & & $-0.855^{* *}$ & 0.731 & $-0.911 * * *$ \\
\hline $\mathrm{N}$ & & 4704 & 4704 & 4704 \\
\hline \multirow{2}{*}{ F test } & & $\mathrm{F}(6,4014)=21.70$ & & \\
\hline & & Prob $>F=0.0000$ & & \\
\hline \multirow{2}{*}{ LM test } & & & Wald chi2 $2(6)=63.26$ & Wald chi2 $(6)=72.36$ \\
\hline & & & Prob $>$ chi $2=0.0000$ & Prob $>$ chi $2=0.0000$ \\
\hline \multirow{2}{*}{ Hausman test } & & $\operatorname{chi} 2(6)=101.43$ & & \\
\hline & & Prob $>$ chi $2=0.0000$ & & \\
\hline \multirow{2}{*}{$\begin{array}{l}\text { Modified } \\
\text { test }\end{array}$} & & $\operatorname{chi} 2(684)=4.3 \mathrm{e}+30$ & & \\
\hline & & Prob $>$ chi $2=0.0000$ & & \\
\hline \multirow{2}{*}{ Wooldridge test } & & $\mathrm{F}(1,607)=4.581$ & & \\
\hline & & Prob $>F=0.0327$ & & \\
\hline
\end{tabular}

Source: calculated by the author from Stata 14.0 
Table 5. Regression results of overinvestment and underinvestment

\begin{tabular}{llll}
\hline & INVEF & OVER & UNDER \\
\hline EQ & $2.101 * * *$ & $3.641^{* * *}$ & $0.251 * * *$ \\
\hline SDEBT & $0.376^{* * * *}$ & $1.304 * * *$ & $0.0507 * * *$ \\
\hline SIZE & 0.00745 & 0.0504 & $0.0160^{* * *}$ \\
\hline Tang & 0.0747 & 0.0157 & $0.190 * * *$ \\
\hline sdCFO & $-0.370 * * *$ & -0.487 & 0.0269 \\
\hline sdREV & -0.046 & -0.00814 & 0.0158 \\
\hline cons & $-0.911 * * *$ & $-3.360 * * *$ & $-0.826 * * *$ \\
\hline $\mathrm{N}$ & 4704 & 1030 & 3674 \\
\hline $\mathrm{t}$ statistics in brackets $* \mathrm{p}<0.1, * * \mathrm{p}<0.05, * * * \mathrm{p}<0.01$ & & \\
\hline
\end{tabular}

Source: calculated by the author from Stata 14.0

To consider the role of EQ and short-term debt in overinvestment and underinvestment, the study continued to use model (1) but replaced the dependent variable in turn by the overinvestment variable OVER (OVER $=$ INVEFF when $\varepsilon_{i, t}$ of regression of equation (3)>0) and underinvestment variable UNDER (UNDER $=$ INVEFF when $\varepsilon_{i, t}$ of regression of equation $(3)<0)$ ). The research findings showed that EQ and debt maturity had a positive impact on overinvestment and underinvestment, in which the impact of EQ and debt maturity on overinvestment are higher than that on underinvestment. For variables controlling the size and tangible fixed asset investment, there is a positive impact on underinvestment and of statistical significance, but there is no impact at all on overinvestment.

Table 6. Regression results of overinvestment and underinvestment when dividing debt levels

\begin{tabular}{llll}
\hline & INVEF & OVER & UNDER \\
\hline EQ & $2.561 * * *$ & $3.600 *$ & $0.244 * *$ \\
\hline SDEBT & $0.337 * * *$ & $1.309 * * *$ & $0.0512 * * *$ \\
\hline EQ*DumSDebt & -0.877 & 0.0822 & 0.0117 \\
\hline SIZE & 0.00808 & 0.0505 & $0.0160 * * *$ \\
\hline Tang & 0.0716 & 0.016 & $0.190 * * *$ \\
\hline sdCFO & $-0.373 * * *$ & -0.486 & 0.0269 \\
\hline sdREV & -0.0481 & -0.00813 & 0.0158 \\
\hline cons & $-0.894 * * *$ & $-3.365 * * *$ & $-0.826 * * *$ \\
\hline $\mathrm{N}$ & 4704 & 1030 & 3674 \\
\hline
\end{tabular}

$\mathrm{t}$ statistics in brackets $* \mathrm{p}<0.1, * * \mathrm{p}<0.05, * * * \mathrm{p}<0.01$

Source: calculated by the author from Stata 14.0

We continued to expand the analysis above by examining whether the use of more short-term debts would increase or decrease the impact of EQ on corporate IE. In order to investigate, we put into the model (2) dummy variables using short-term DumSTDebt value of 1 when the enterprise has a ratio of short-term debt to total debt greater than the median value of the debt maturity among all the companies in the sample considering that an enterprise used a lot of short-term debts. In contrast, for enterprises with SDebt smaller than the median value of the whole sample, DumSTDebt with a value of 0 , it means that enterprises use less short-term debts. Table 5 presented the results of the regression equation (2) between the investment efficiency variable and the EQ margins, debt maturity, dummy variable for the use of short-term debts, the interaction variable between EQ and short-term debt utilization as well as some of the other control variables discussed above. The results from Table 6 showed that the impact of EQ on corporate IE is 
not different at various levels of short-term debt use because the coefficient of the interaction variable between EQ and the dummy variable for short-term debt use is not of statistical significance; hypothesis H6 is rejected. This can be explained by the fact that different levels of short-term debts do not entirely affect the assessment of EQ when making investments as EQ is reflected in many other criteria and aspects, and no links have been found between EQ and higher short-term debt usage. However, considering only the sign of the regression coefficient -0.877), it can be concluded that at the lower level of short-term debt usage, EQ has a higher impact in EI improvement at higher level of short-term debt utilization. The sign of this coefficient is similar to that of (Gomariz \& Ballesta, 2014). Similar to IE regression, the effect of EQ on overinvestment and underinvestment has made no difference at various levels of short-term debt usage.

\section{Conclusions and Recommendations}

\subsection{Conclusion}

A sample of 4704 observations at listed companies on Vietnam stock market in the period from 2010 to 2018 was used to examine the relationship between EQ and debt maturity of enterprises on IE. The study showed that EQ revealed its role in improving corporate IE. Accordingly, when EQ increases, firms will have a basis for assessing the business situation, financial health, creditworthiness, anticipating the cash flow of the project and corporate risks more accurately and timely, thereby better project planning and bringing in higher investment efficiency for businesses. In addition, financial statements of good quality shall restrict the information asymmetry and become an effective tool to help shareholders and creditors to strengthen the control of management of the corporate management board, thereby limit the representative costs. Besides, a good EQ will be the best, the most intuitive, the simplest as well as the most popular means of attracting foreign investors to invest in the company when the firm is in need of raising capital for upcoming projects.

For short-term debt maturity, the regression results showed that the ratio of short-term debt to total debt contributed to the improvement of the corporate IE. When businesses use a lot of short-term debt, the ability to pay capital and interest of the business will be easier, businesses shall not be under too much pressure of debt repayment (due to lower interest rates) but still take advantage of the tax shield of a loan. In addition, the use of short-term debt will contribute to limiting the overinvestment and underinvestment, thus facilitate the improvement of investment efficiency. On the other hand, when using short-term debt, the risk level of the business will be lower, thus improving the credit rating. At the same time, the use of short-term debt also helps minimize the information asymmetry because the longer debt maturity will worsen the problem of asymmetric information of the business. Combining all of the above factors, using a lot of short-term debts will contribute to reducing cost of capital, thereby improving the corporate IE.

\subsection{Recommendations}

However, at the level of the research, the paper will provide some suggestions and recommendations regarding the evaluation of project selection to enhance IE and limit overinvestment of Vietnamese businesses in the near future, specifically:

- Enterprises need to focus on preparing their company's financial statements, ensuring accurate and adequate input and output figures as well as conforming to Vietnamese and international accounting standards, thereby enhancing the quality of financial statements. In addition, the audit of financial statements should be conducted by reputable auditing companies in order to provide organizations, individuals and investors with accurate and objective information about the business situation and financial status of the company.

- Corporate planning of investment projects needs to be closely conducted on the basis of considering and calculating all relevant factors and risks. In particular, businesses cannot overlook the importance of evaluating financial statements as the information in such reports shall provide useful suggestions for businesses to evaluate the efficiency of investment projects, avoid making mistakes of rejecting projects with positive NPV or accepting projects with a negative NPV.

- Enterprises should establish for themselves a reasonable capital structure based on the specific characteristics of the business sector as well as their financial health and position in the market. There should be a flexible coordination between short-term debt and long-term debt on the basis of ensuring the corporate solvency as well as helping businesses take advantage of the benefits of borrowing.

- In addition to focusing on their financial statements and debt structure, firms also need to improve their own financial capacity, focusing on building up measures to prevent business risks and financial risks to improve the financial health as well as the company's ability to adapt to changes in the market during the process of investment and project implementation. 
- In the process of implementing investment projects, Vietnamese enterprises are required to consider the impacts of the project on the environment, culture and society. The implementation of projects that have adverse effect on the community and human health as well as polluting the environment should be restricted.

\section{Acknowledgements}

This research is funded by Vietnam National Foundation for Science and Technology Development (NAFOSTED) under grant number 502.02-2019.302

\section{References}

Ball, R., \& Shivakumar, L. (2005). Earnings quality in UK private firms: comparative loss recognition timeliness. Journal of Accounting and Economics, 39(1), 83-128. https://doi.org/10.1016/j.jacceco.2004.04.001

Barclay, M. J., \& Smith, C. W. Jr. (1995). The maturity structure of corporate debt. The Journal of Finance, 50(2), 609-631. https://doi.org/10.1111/j.1540-6261.1995.tb04797.x

Beneish, M. D., \& Vargus, M. E. (2002). Insider trading, earnings quality, and accrual mispricing. The Accounting Review, 77(4), 755-791. https://doi.org/10.2308/accr.2002.77.4.755

Berger, A. N., \& Udell, G. F. (1998). The economics of small business finance: The roles of private equity and debt markets in the financial growth cycle. Journal of Banking \& Finance, 22(6-8), 613-673. https://doi.org/10.1016/S0378-4266(98)00038-7

Bhattacharya, U., Daouk, H., \& Welker, M. (2003). The world price of earnings opacity. The Accounting Review, 78(3), 641-678. https://doi.org/10.2308/accr.2003.78.3.641

Biddle, G. C., \& Hilary, G. (2006). Accounting quality and firm-level capital investment. The Accounting Review, 81(5), 963-982. https://doi.org/10.2308/accr.2006.81.5.963

Biddle, G. C., Hilary, G., \& Verdi, R. S. (2009). How does financial reporting quality relate to investment efficiency?. Journal of Accounting and Economics, 48(2-3), 112-131. https://doi.org/10.1016/j.jacceco.2009.09.001

Burgstahler, D. C., Hail, L., \& Leuz, C. (2006). The importance of reporting incentives: Earnings management in European private and public firms. The Accounting Review, 81(5), 983-1016. https://doi.org/10.2308/accr.2006.81.5.983

Bushman, R. M., \& Smith, A. J. (2001). Financial accounting information and corporate governance. Journal of Accounting and Economics, 32(1-3), 237-333. https://doi.org/10.1016/S0165-4101(01)00027-1

Chen, F., Hope, O.-K., Li, Q., \& Wang, X. (2011). Financial reporting quality and investment efficiency of private firms in emerging markets. The Accounting Review, 86(4), 1255-1288. https://doi.org/10.2308/accr-10040

Cherkasova, V., \& Rasadi, D. (2017). Earnings quality and investment efficiency: evidence from Eastern Europe. Review of Economic Perspectives, 17(4), 441-468. 10.1515/revecp-2017-0023

Childs, P. D., Mauer, D. C., \& Ott, S. H. (2005). Interactions of corporate financing and investment decisions: The effects of agency conflicts. Journal of Financial Economics, 76(3), 667-690. https://doi.org/10.1016/j.jfineco.2004.06.012

Dang, H. N., Vu, V. T. T., Ngo, X. T., \& Hoang, H. T. V. (2019). Study the Impact of Growth, Firm Size, Capital Structure, and Profitability on Enterprise Value: Evidence of Enterprises in Vietnam. Journal of Corporate Accounting \& Finance, 30(1), 144-160. https://doi.org/10.1002/jcaf.22371

Dang, N. H., Tran, B. M., \& Tran, M. D. (2019). Impact of Dividend Policy on Variation of Stock Prices: Empirical Study of Vietnam. Journal of Economics and Development, 21(Special Issue), 96-106.

De Carvalho, F. L., Kalatzis, A. E. G., \& De Albuquerque, A. A. (2014). The relationship between earnings quality and the probability of efficient investment decisions in Latin America. Latin American Journal of Management for Sustainable Development, 1(2-3), 229-250. https://doi.org/10.1504/LAJMSD.2014.065481

Dichev, I. D., \& Tang, V. W. (2009). Earnings volatility and earnings predictability. Journal of Accounting and Economics, 47(1-2), 160-181. http://doi.org/10.1016/j.jacceco.2008.09.005

Francis, J. R., \& Wang, D. (2008). The joint effect of investor protection and Big 4 audits on earnings quality around the world. Contemporary Accounting Research, 25(1), 157-191. https://doi.org/10.1506/car.25.1.6

Francis, J., LaFond, R., Olsson, P. M., \& Schipper, K. (2004). Costs of equity and earnings attributes. The Accounting Review, 79(4), 967-1010. https://doi.org/10.2308/accr.2004.79.4.967 
Gomariz, M. F. C., \& Ballesta, J. P. S. (2014). Financial reporting quality, debt maturity and investment efficiency. Journal of Banking \& Finance, 40, 494-506. https://doi.org/10.1016/j.jbankfin.2013.07.013

Healy, P. M., \& Palepu, K. G. (2001). Information asymmetry, corporate disclosure, and the capital markets: A review of the empirical disclosure literature. Journal of Accounting and Economics, 31(1-3), 405-440. https://doi.org/10.1016/S0165-4101(01)00018-0

Holthausen, R. W. (2009). Accounting standards, financial reporting outcomes, and enforcement. Journal of Accounting Research, 47(2), 447-458. https://doi.org/10.1111/j.1475-679X.2009.00330.x

Hope, O. K., \& Thomas, W. B. (2008). Managerial empire building and firm disclosure. Journal of Accounting Research, 46(3), 591-626. https://doi.org/10.1111/j.1475-679X.2008.00289.x

Houcine, A. (2017). The effect of financial reporting quality on corporate investment efficiency: Evidence from the Tunisian stock market. Research in International Business and Finance, 42, 321-337. https://doi.org/10.1016/j.ribaf.2017.07.066

Hung, D. N., Ha, H. T. V., \& Binh, D. T. (2018). Impact of accounting information on financial statements to the stock price of the energy enterprises listed on Vietnam's stock market. International Journal of Energy Economics and Policy, 8(2), 1-6.

Kim, O., \& Verrecchia, R. E. (1994). Market liquidity and volume around earnings announcements. Journal of Accounting and Economics, 17(1-2), 41-67. https://doi.org/10.1016/0165-4101(94)90004-3

Lambert, R., Leuz, C., \& Verrecchia, R. E. (2007). Accounting information, disclosure, and the cost of capital. Journal of Accounting Research, 45(2), 385-420. https://doi.org/10.1111/j.1475-679X.2007.00238.x

Leuz, C., Nanda, D., \& Wysocki, P. D. (2003). Earnings management and investor protection: an international comparison. Journal of Financial Economics, 69(3), 505-527. https://doi.org/10.1016/S0304-405X(03)00121-1

Li, F. (2011). Earnings quality based on corporate investment decisions. Journal of Accounting Research, 49(3), 721-752. https://doi.org/10.1111/j.1475-679X.2010.00397.x

McNichols, M. F., \& Stubben, S. R. (2008). Does earnings management affect firms' investment decisions?. The Accounting Review, 83(6), 1571-1603. https://doi.org/10.2308/accr.2008.83.6.1571

Myers, S. C. (1977). Determinants of corporate borrowing. Journal of Financial Economics, 5(2), 147-175. https://doi.org/10.1016/0304-405X(77)90015-0

Nguyen, H. T., \& Nguyen, D. T. N. (2019). The impact of country-level and fund-level factors on mutual fund performance in Vietnam. Journal of Economics and Development, 21(1), 42-56.

Ortiz-Molina, H., \& Penas, M. F. (2008). Lending to small businesses: The role of loan maturity in addressing information problems. Small Business Economics, 30(4), 361-383. https://doi.org/10.1007/s11187-007-9053-2

Penman, S. H., \& Zhang, X.-J. (2002). Accounting conservatism, the quality of earnings, and stock returns. The Accounting Review, 77(2), 237-264. https://doi.org/10.2308/accr.2002.77.2.237

Rezaee, Z., \& Tuo, L. (2017). Are the quantity and quality of sustainability disclosures associated with the innate and discretionary earnings quality?. Journal of Business Ethics, 1-24. http://doi.org/10.1007/s10551-017-3546-y

Richardson, S. A., Sloan, R. G., Soliman, M. T., \& Tuna, A. (2001). Information in Accruals about the Quality of Earnings (pp. 1-52).

Van Linh, N., Hung, D. N., Dang, T. B., Van, V. T. T., \& Anh, N. T. M. (2019). The Effects of Business Efficiency to Disclose Information of Sustainable Development: The Case of Vietnam. Asian Economic and Financial Review, 9(4), 547-558. 